\title{
Testing Relationship between Government Current Expenditures and Economic Growth in Nigeria
}

\author{
Sebastian 0. Uremadu1 ${ }^{*}$, Patience C. Orikara ${ }^{2}$, Charity E. Uremadu ${ }^{3}$ \\ ${ }^{1}$ Department of Banking and Finance, College of Management Sciences (COLMAS), Michael Okpara University of Agriculture, \\ Umudike, Nigeria \\ ${ }^{2}$ Abia State Internal Revenue Service Board, Umuahia, Nigeria \\ ${ }^{3}$ Department of Educational Management, College of Education, COED, Michael Okpara University of Agriculture, \\ Umudike, Nigeria \\ Email: ^sebauremadu@yahoo.com, csteveorikara@yahoo.com,rityeuremadu@yahoo.com
}

How to cite this paper: Uremadu, S.O. Orikara, P.C. and Uremadu, C.E. (2019) Testing Relationship between Government Current Expenditures and Economic Growth in Nigeria. Theoretical Economics Letters, 9, 584-604.

https://doi.org/10.4236/tel.2019.94041

Received: May 29, 2018

Accepted: March 25, 2019

Published: March 28, 2019

Copyright (C) 2019 by author(s) and Scientific Research Publishing Inc. This work is licensed under the Creative Commons Attribution International License (CC BY 4.0).

http://creativecommons.org/licenses/by/4.0/

\begin{abstract}
This study investigates the relationship between government recurrent expenditures and economic growth in Nigeria for 18 years: 1999-2016. In doing this, the paper disaggregated government current expenditures into five categories used as explanatory variables. The estimated result showed that influence of government expenditures on national assembly, pensions and gratuities had insignificant effect on economic growth. However, total government expenditures on administration and public debt servicing had a positive and significant effect on economic growth. Also the study revealed that total government expenditures on transfers had insignificant effect on economic growth. Study therefore recommends that annual government recurrent expenditures on administration and public debt servicing should be sustained as they led to economic growth, but that all leakages arising from such spending should be blocked in order to achieve an enhanced growth.
\end{abstract}

\section{Keywords}

Government Recurrent Expenditures, Economic Growth, National Assembly, Public Debt Servicing, Pensions and Gratuities, Administration, Transfers

\section{Introduction}

\subsection{Background to the Study}

In the views of the Keynesians, government has a role to play in achieving eco- 
nomic growth among nations of the world. This is against the backdrop that the government has the primary responsibility of providing public goods which the private sector may not have the capacity to provide such as roads, security, electricity, hospitals etc. [1] [2]. Nevertheless, government expenditure in the Keynesians ideology tends to acknowledge the effective contribution of government capital expenditure towards achieving economic growth rather than government recurrent expenditure [3] [4]. Therefore, one tends to wonder whether government recurrent expenditures actually matter.

In Nigeria, government recurrent expenditures have continued to rise especially since the inception of the democratic era in Nigeria that began in 1999. Available data showed that government recurrent expenditure was a mere N449.66 billion in 1999 and increased steadily reaching N984.30 billion in 2003 [5]. In 2004, it went higher reaching an estimated N1.11 trillion and this upward trend has continued with government recurrent expenditure reaching a whopping N2.12 trillion in 2008 [5]. From an estimated N2.13 trillion in 2009, government recurrent expenditure in Nigeria rose to a staggering N3.33 trillion in 2012. There was a slight downward trend in 2013 when government expenditure decreased to N3.21 trillion but this was quickly reversed as government recurrent expenditure steadily increased reaching an estimated high value of N4.18 trillion in 2016 [5]. The ever-increasing government recurrent expenditures in Nigeria has attracted lots of complaints and criticisms from the Nigerian populace who argued that the government was wasteful and that the much they spent on servicing recurrent components of government should have been channeled to capital projects [6] [7]. The impression being created by this argument is that recurrent expenditure does not increase economic growth in Nigeria. Thus, this study is coming on the heels of this argument and the need to empirically investigate the veracity or otherwise of this assertion. By the time the study is completed the researchers shall be able to ascertain which way forward.

\subsection{Statement of the Problem}

With the enthronement of democracy in Nigeria came the persistent increase in national Assembly recurrent expenditure. This has attracted so much attacks from those outside the confines of the national assembly who have argued that increased spending on things such as payment of wardrobe allowances to members of the national assembly, buying of new cars for members almost on yearly basis, payment for sitting allowance to members per sitting, increase in salaries of members and other financial benefits will only rip the nation off her hard earned resources thereby retarding economic growth of the nation [8].

Nigeria's domestic and foreign debts have continued to increase over the years with every civilian administration justifying why it must borrow. Painfully, servicing of these debts eat deeply into the nation's treasury. This is because as interest rate attached to these loans increases, more funds are deployed to service these debts with the resultant effect being a fall in government investment in such things as provision and maintenance of public infrastructures, education, 
health, etc. As government fails to provide the needed infrastructures, economic activities suffered, productivity is adversely affected thereby reducing economic growth [9].

Previous studies had been carried out on the relationship between government spending and economic growth in Nigeria. For instance, Kareem et al. [10]; Ukwureze [11]; Njoku et al. [12]; Omo and Bashir [13]; Ogbuagu and Ekpenyong [14]; Shuaib et al. [15]; Udoffia and Godson [16]; Olayemi [17]; Obialor [18]; Nwankwo et al. [19]; Nwoha et al. [20] and others. They had varying results and findings on the effect of government expenditures on economic growth in Nigeria had been a mixed bag. In all the previous studies consulted, government expenditure was broadly categorized into recurrent expenditure and capital expenditures and their effects on economic growth were clearly determined. Even when the studies disaggregated government expenditure into spending on health, education etc; these studies also failed to establish whether such spending was done in the recurrent or capital side since both recurrent and capital government expenditures were made up of spending in health, education and the likes. With these past studies, it was empirically difficult to determine which side of government spending resulted in economic growth thereby creating a gap in literature on the Nigerian studies. As a matter of fact, most past studies have centered mainly on public expenditure with minimal works were yet doe on government recurrent expenditure in particular, thereby necessitating the need for the present study. As a matter of fact, most past studies are centred mainly on public expenditures with minimally works yet to be done on government recurrent expenditures in particular thereby necessitating the need for the present study. To fill this gap, this study would lay emphasis on the recurrent side of government expenditures and disaggregate it into government recurrent expenditures of the national assembly, government recurrent expenditures of public debt servicing, government recurrent expenditures of pensions and gratuities, government recurrent expenditures of administration and government recurrent expenditures of transfers, etc. By the time this study is concluded the researchers shall be in a position to ascertain which way forward on the relationship between government recurrent expenditures and or degree of their association in Nigeria toward growth of the domestic economy.

\subsection{Research Contributions}

The broad objective of the present study is to examine the relationship between government recurrent expenditure and economic growth in Nigeria. Specifically, the objective of the study is fivefold which is out to investigate impact of government expenditures of national assembly, public debt servicing, pension and gratuities, administration and transfers on the domestic economy.

In line with the above specified research objectives, the study is aimed at providing answers to these composite research questions: to what extent or degree have government recurrent expenditures of national assembly, public debt servicing, pension and gratuities, administration and transfers impacted on the 
economy of Nigeria.

Finally, the paper at this point hypothesize that government recurrent expenditures of national assembly, public debt servicing, pension and gratuities, administration and transfers do not have a positive and significant impact on the domestic economy of Nigeria.

\section{Review of Related Literature}

\subsection{The Review}

In the literature review for this study some relevant variables for the study have been conceptualized among which are named and conceptually discussed hereunder:

\subsubsection{Concept of Government Expenditure}

Government expenditure has been given various meanings depending on whether one considers it in terms of its recurrent nature, its capital nature and/or criteria for government spending. Okoro [21] opined that government expenditure was borne out of revenue allocation and as a way of redistributing wealth amongst its citizens. Okoro [21] further argued that government expenditure offers the platform for the different tiers of government to dispose its responsibilities to its subjects. By and large, Okoro [21] defined government expenditure as the value of goods and services provided through the public sector. Nwaeze et al. [22] saw government expenditure as those spending of government made for its own maintenance, societal benefits, and economic benefits and even for the benefit of other countries. Interestingly, Njoku et al. [12], conceptualized government expenditure as spending that the government made from revenues it derived from taxes and other sources. No wonder, Campodpnico et al. [23] stated that government expenditure included those expenditures made by government in order to influence economic growth, poverty and income distribution. In the views of Ewubare and Eyitope [24] government expenditure refers to the main instrument at the disposal of government (both in developed and developing countries) needed to usher in better standard of living for its citizens.

\subsubsection{Concept of Recurrent Expenditure}

Unlike capital expenditure in which the purchase of goods and services is done with the hope of adding value or increasing productivity, recurrent expenditures are those expenditures on goods and services which do not lead to creation or acquisition of fixed assets. Rather, it is mainly expenditures made for the day-today running of a firm or government establishments that cover ministries, departments and agencies (MDAs) as they are called in Nigeria. To this extent, recurrent expenditures include expenditures made for payment of overheads, salaries, interest payments, subsidies, transfers, pensions and gratuities, etc. It is often argued that the purpose of recurrent expenditure is to maintain a company's or government's ability to operate. Little wonder, recurrent expenditure is of a continuous nature unlike the one-off nature of most capital expenditures [25]. 
As a matter of fact, maintaining adequate government recurrent expenditures is as good as saying that there exists adequate liquidity for the government agencies, departments and ministries to run or function without interruptions.

\subsubsection{Concept of Economic Growth}

Economic growth could be broadly referred to as an increase in total value of goods and services produced in a country on annual basis [22]. In relative and absolute terms, economic growth could be conceptualized as an increase in gross domestic product (GDP), gross national product (GNP) and national income (NI). Thus, economic growth represents an increase in the size of national economies especially the gross domestic product per capita (GDP per capita) of individuals living in that country. Based on the foregoing, IMF [26], classified economic growth as positive, negative and zero depending on the experiences of nations. For instance, positive economic growth occurs when national annual average macroeconomic indicators exceed the average growth of the national population growth. Conversely, a negative economic growth arises when the national annual average growth of macroeconomic indicators is less than the growth of the national population growth. Zero economic growth could occur when the growth of annual macroeconomic indicators is equal to the growth of the national population. In another sphere, economic growth is classified as either intensive or extensive. Economic growth is classified as intensive when an increase in economic growth is caused by more efficient use of inputs such as labour, physical capital, energy or materials. Nevertheless, extensive economic growth could occur when an increase in national growth is caused only by increase in the amount of inputs available for use [27].

\subsection{Theoretical Framework for the Study}

Two theories of government (public) expenditures have been reviewed in this study namely the Keynesian theory and Wagner's theory.

\subsubsection{Keynesian Theory}

The Keynesian theory of government expenditure was postulated by a British economist John Maynard Keynes and became popularized during the great depression in the 1930s. The Keynesian theory is premised on four major assumptions and these assumptions distinguished the Keynesian school of thought from others. The assumptions include: 1) government has a role in the economy, 2) self-regulatory mechanism of the free-market economy fails, 3) use of fiscal policies to boost the economy, and 4) Causality runs from government expenditure to economic growth [28].

\subsubsection{Wagner's Theory}

The Wagner' theory or hypothesis was postulated by Adolf Wagner, a German political economist in 1839. It is a theory that explains the trend in the growth of public expenditure and argues that a cause and effect nexus exists between growth of an industrializing nation and growth of public (government) expend- 
iture. Wagner's theory has its foundational argument on the premise that public expenditure was as a result of growth in the economy of industrialized nations. As the economy grows, it is expected that government expenditure will increase. According to the theory, as per capita income and output of industrializing countries increase, public (government) expenditures will also increase as a proportion of total economic activity.

\subsection{Empirical Literature}

Nworji and Oluwalaiye [29] investigated the impact of government spending on economic growth in Nigeria for the period 1980 to 2009. The study adopted government expenditures on road infrastructure, defense, transportation and communication and inflation rate as the independent variables. Gross domestic product served as the dependent variable. Ordinary least squares (OLS) multiple regression technique was used and findings showed that government expenditure on transport and communication had a positive and significant effect on economic growth in Nigeria. More so, the study showed that government expenditure on defence had a positive and significant impact on economic growth while inflation rate had a positive and insignificant impact on economic growth in Nigeria.

Adewara and Oloni [30] examined the effect of public expenditure on economic growth in Nigeria for the period 1980 to 2011. The study adopted government expenditures on health, education, defense, investment, agriculture, water and transportation as proxies for public expenditure. The study used vector autoregression (VAR) as its methodology and findings showed that government expenditure on agriculture and transportation had positive and significant impact on economic growth. However, health, education, defense, investment, and water expenditures had negative and significant impact on economic growth in Nigeria.

Ogbulu and Torbira [31] empirically investigated the relationship between budgetary operations and economic growth in Nigeria from 1972 to 2008. The study adopted oil revenue, non-oil revenue, administrative expenditure, economic expenditure, social expenditure and transfer expenditure as proxies for budgetary operations while gross domestic product was the proxy for economic growth. The study used Augmented Dickey-Fuller test, Johansen cointegration test and error correction mechanism (ECM) as empirical tools of analysis. Findings showed that transfer expenditure had a positive and significant effect on economic growth while oil revenue had a negative and insignificant impact on economic growth. However, non-oil revenue and government expenditure on administration had positive and insignificant impact on economic growth whereas economic expenditure and social expenditure had a negative and insignificant impact on economic growth of Nigeria.

Dada [32] analyzed the effects of government expenditure on private consumption and output growth in Nigeria for the period 1961 to 2010. The study disaggregated government expenditure into government expenditure on admin- 
istration, education and health, agriculture, construction, transport and communication and social security. Descriptive analysis, unit root test, cointegration test and error correction mechanism (ECM) were performed. Findings showed that government expenditure had a positive and significant impact on both private consumption and economic growth in Nigeria especially in the long run. To this extent, the study argued that government expenditure on education and health, and social security had a crowding-in effect on private consumption. Thus, government expenditure on education and health and social security increased private consumption. However, government expenditure on administration, construction, agriculture, transport and communication had a crowding-out effect showing that they decreased private consumption in Nigeria.

Okoro [21] examined the nexus between government expenditure and economic growth in Nigeria for the period 1980 to 2011. Real gross domestic product was adopted as proxy for economic growth while government capital expenditure and government recurrent expenditure were proxies for government expenditure. Unit root test, Granger-causality test, cointegration test and error correction mechanism (ECM) were employed as analytical tools. The study revealed that government capital expenditure had a negative and insignificant impact on economic growth in Nigeria while government recurrent expenditure had a positive and significant impact on economic growth in Nigeria.

Kareem et al. [10] conducted an investigation on the impact of public sector spending on economic growth of Nigeria for the period 1960 to 2010. The aggregated analysis adopted government capital expenditure and government recurrent expenditure as the independent variables while the disaggregated analysis adopted government expenditures on agriculture, administration, industry, social and community services, economic service, health, transport, industry, education and services sector as the independent variables. The study employed the unit root test, cointegration test and ordinary least squares (OLS) multiple regression technique in its analysis. Findings showed that government capital expenditure had a negative and significant impact on economic growth while government recurrent expenditure had a positive and significant impact on economic growth in Nigeria. The study also revealed that government expenditure on agriculture, government expenditure on industry and government expenditure on the services sector had a positive and significant impact on economic growth. However, government expenditure on administration, social and community services and government expenditure on health had negative and significant impact on economic growth. Finally, government expenditure on transport and education had a positive but insignificant impact on economic growth.

Njoku et al. [12] investigated the relationship between public expenditure and economic growth in Nigeria for the period 1983 to 2012. Health, education, defense, agriculture and transport and communication expenditures were adopted as proxies for public expenditure while gross domestic product served as proxy for economic growth. The study employed ADF unit root test, Johansen cointe- 
gration test and Granger-causality test as the empirical tools. Findings showed that there existed a bi-directional relationship between government expenditure on agriculture and gross domestic product. Government expenditure on agriculture drove economic growth and at the same time economic growth drove government expenditure on agriculture in Nigeria. However, the study revealed that unidirectional relationship existed between defense expenditure and GDP with the flow of causation running from GDP to government expenditure on defense.

Omo and Bashir [13], considered the relationship between oil revenue, public spending and economic growth in Nigeria for the period 1980 to 2015. Oil revenue and government expenditure were the independent variables while real gross domestic product was the dependent variable. Unit root test, cointegration test, Granger-Causality test and error correction mechanism (ECM) were used as the analytical tools. Findings showed that oil revenue drove level of economic growth and government spending. However, the study showed that there was no relationship between government spending and growth in Nigeria. Hence, government spending did not drive economic growth and economic growth did not drive government spending. Finally, the study showed that oil revenue had a positive and significant impact on economic growth while public spending had a positive and weak significant impact on economic growth.

Ogbuagu and Ekpenyong [14] looked at the impact of the components of public expenditure on economic growth in Nigeria from 1970 to 2014. Recurrent expenditure, capital expenditure, net exports, inflation rate and gross national savings served as the independent variables while gross domestic product served as the dependent variable. Unit root test, Toda-Yamamoto causality test and auto-regression distributive lag (ARDL) technique were used as analytical tools. Findings showed that recurrent expenditure had a positive and significant impact on economic growth both in the short run and long run. However, the study showed that capital expenditure had no short run effect on economic growth but rather exhibited a negative significant effect on economic growth only in the long run. National savings had negative and significant impact on economic growth in the short run but a positive and significant effect in the long run. Finally, the study revealed that net exports had a negative impact on economic growth in Nigeria.

Ojonugwa et al. [33] examined the relationship between government expenditure and economic growth in Nigeria for the period 1970 to 2010. Recurrent expenditure and capital expenditure were adopted as proxies for government expenditure while real gross domestic product was proxy for economic growth. Unit root test, cointegration test, Pair-wise cointegration test and Granger-causality test were empirical tools used in the analysis. The study showed that both capital expenditure and recurrent expenditure had a positive and significant relationship with economic growth in the long run. Recurrent expenditure exhibited a positive and significant relationship with economic growth in the short run while capital expenditure had a negative but significant relationship with 
economic growth in the short run. The Pair-wise Granger-causality test showed that there was a unidirectional causality running from economic growth to both capital and recurrent expenditures showing that economic growth determined both capital and recurrent expenditures in Nigeria.

Gushibet and Tsenba [4], tested the impact of public expenditure on economic growth in Nigeria for the democratic era that covered the period 2000 to 2014. The study adopted aggregate government revenue, aggregate government expenditure, recurrent expenditure, capital expenditure, public debt and corruption as the explanatory variables while GDP served as the dependent variable. Unit root test, cointegration test and the ordinary least squares (OLS) multiple regression analysis were employed as analytical tools. The study showed that government revenue had a positive but insignificant relationship with economic growth. Total government expenditure had a positive and significant relationship with economic growth in Nigeria while recurrent expenditure had a negative and weak significant impact on economic growth in Nigeria. More so, the study revealed that capital expenditure had a positive but insignificant impact on economic growth and public debt exhibited a positive and insignificant impact on economic growth.

Udoffia and Godson [16] analyzed the impact of federal government expenditure on economic growth in Nigeria for the period 1981 to 2014. Real gross domestic product served as the proxy for economic growth and it served as the dependent variable while recurrent expenditure and capital expenditure served as federal government expenditure and these served as the independent variables. The study used the descriptive statistic methodology, unit root test and the ordinary least squares (OLS) multiple regression technique in its tests and analysis. Findings showed that recurrent and capital expenditures of federal government had a positive and significant effect on economic growth in Nigeria.

Olayemi [17] analyzed the relationship between growth in Nigeria and public spending. The study anchored on Ram framework for the period 1981 to 2016 . Government expenditure in health, government expenditure on education, government expenditure on consumption expenditure and private sector investment were adopted as the independent variables. However, real gross domestic product served as the dependent variable. In the study, government expenditure on health and education were classified as government expenditure on human capital development. The study used the Autoregressive Distributed Lag (ARDL) model as its analytical tool. Findings showed that government expenditure on human capital development had more significant impact on economic growth in the long run while government expenditure on consumption and private sector investment also had significant impact on economic growth in the long run but at a lesser scale.

Nwoha et al. [20] investigated the effect of aggregated and disaggregated government expenditure on economic growth in Nigeria for the period 1980 to 2015. The study adopted aggregated government expenditure (proxied by total federal government expenditure). Disaggregated expenditure was proxied by 
recurrent expenditure and capital expenditure while real gross domestic product served as proxy for economic growth. All of total government expenditure, recurrent expenditure and capital expenditure served as the independent variables while real GDP served as the dependent variable. The study used the error correction mechanism (ECM) as the empirical tool for its tests and analysis. Findings showed that total federal government expenditure and capital expenditure had positive and significant effect on economic growth in Nigeria. On the other hand, the study revealed that recurrent expenditure had a positive and insignificant effect on economic growth in Nigeria.

All these above considered body of literature have established existence of premise for the study of government recurrent expenditures and growth in $\mathrm{Ni}$ geria.

\section{Methodology}

In this section, the paper will discuss methods to be followed in the conduct of tests and analysis for the study.

\subsection{Research Design for the Study}

The study adopted the ex-postfacto research design. The ex-post facto research design is considered in this study because of its cause-effect nature. Based on the specific objectives of the study, efforts are made to establish the impact of the relevent independent variables (i.e. government recurrent expenditures on national assembly, public debt servicing, pensions and gratuities, administration and transfers) on the dependent variable (i.e. gross domestic product) using existing data. According to Osuala [34] the ex-postfacto research design is appropriate and preferred in a cause-effect relationship where there is already existing data which could be manipulated by the researcher. Given that the data on GDP in Nigeria already exists and on the other hand, the data on the independent variables: national assembly recurrent expenditure, public debt servicing recurrent expenditure, pensions and gratuities recurrent expenditure, recurrent expenditure on administration, and recurrent expenditure on transfers) in Nigeria also exists; the ex-post facto research design is considered most appropriate for the present study.

\subsection{Sources of Data for the Study}

The study made use of secondary data which have been collected from the Central Bank of Nigeria (CBN) Statistical Bulletin, volume 17, December 2016 (various). Data on gross domestic product (proxy for economic growth), national assembly recurrent expenditure, public debt servicing recurrent expenditure, pensions and gratuities recurrent expenditure, total government recurrent expenditure on administration and total government recurrent expenditure on transfers were all collected from the CBN Statistical Bulletin for various times covered in the study. 


\subsection{Model Specification}

This study has been anchored on the Keynesian theory which established the importance of government expenditure in achieving economic growth of a nation state. Okoro [21] argued that the link between government expenditures and real gross domestic product (real GDP) growth in Nigeria could be specified by a model stated as:

$$
\mathrm{RGDP}=\mathrm{f}(\mathrm{GCEXP}, \mathrm{GREXP})
$$

where, RGDP is Real gross domestic product; GCEXP is Government capital expenditure; GREXP is Government recurrent expenditure.

In line with Okoro [21] with some minor modifications, the model for the study is therefore specified below as:

$$
\text { GDP }=\mathrm{f}(\text { GRENA, GREPDTS, GREPENG, TGRA, TGRT })
$$

where;

RGDP $=$ Real gross domestic product (proxy for economic growth)

GRENA = Government recurrent expenditure on national assembly

GREPDTS $=$ Government recurrent expenditure on public debt servicing

GREPENG = Government recurrent expenditure on pensions and gratuities

TGRA $=$ Total government recurrent expenditure on administration

TGRT $=$ Total government recurrent expenditure on transfers

$\mathrm{f}=$ functional relationship notation

Transforming model Equation (2) into its linear econometric form, we have

$$
\begin{aligned}
\mathrm{RGDP}= & \beta_{0}+\beta_{1} \text { GRENA }+\beta_{2} \text { GREPDTS }+\beta_{3} \text { GREPENG } \\
& +\beta_{4} \text { TGRA }+\beta_{5} \text { TGRT }+\mu_{t}
\end{aligned}
$$

where;

$\beta_{0}=$ constant term

$\beta_{1}, \beta_{2}, \beta_{3}, \beta_{4}$ and $\beta_{5}=$ coefficient parameters for the explanatory variables

$\mu=$ stochastic error term

By a priori $\beta_{0}>0, \beta_{1}>0, \beta_{2}>0, \beta_{3}>0, \beta_{4}>0, \beta_{5}>0$

Transforming model Equation (3) into a common base for all the variables using logarithmic function, the regression equation becomes:

$$
\begin{aligned}
\ln (\text { RGDP })= & \beta_{0}+\beta_{1} \ln (\text { GRENA })+\beta_{2} \ln (\text { GREPDTS })+\beta_{3} \ln (\text { GREPENG }) \\
& +\beta_{4} \ln (\text { TGRA })+\beta_{5} \ln (\text { TGRT })+\mu_{t}
\end{aligned}
$$

The data will then be applied in the model Equation (4) to enable the study conduct its tests and analysis.

\section{Data Presentation and Analysis}

Below we present data for the study in Table 1 and subsequently analyze the data afterwards.

Here, the paper shall execute data analysis arising from Table 1, item by item, below. 
Table 1. Showing time series data on Real Gross Domestic Product (RGDP) and other relevant indicators of expenditure and growth.

\begin{tabular}{|c|c|c|c|c|c|c|}
\hline YEAR & $\begin{array}{l}\text { Real Gross } \\
\text { Domestic } \\
\text { Products } \\
\text { (RGDP) }\end{array}$ & $\begin{array}{c}\text { Government } \\
\text { Recurrent } \\
\text { Expenditure } \\
\text { on National } \\
\text { Assembly } \\
\text { (GRENA) }\end{array}$ & $\begin{array}{l}\text { Government } \\
\text { Recurrent } \\
\text { Expenditure } \\
\text { on Public } \\
\text { Debt Servicing } \\
\text { (GREPDTS) }\end{array}$ & $\begin{array}{l}\text { Government } \\
\text { Recurrent } \\
\text { Expenditure } \\
\text { on Pensions } \\
\text { and Gratuities } \\
\text { (GREPENG) }\end{array}$ & $\begin{array}{c}\text { Total } \\
\text { Government } \\
\text { Recurrent } \\
\text { Expenditure } \\
\text { on Administration } \\
\text { (TGRA) }\end{array}$ & $\begin{array}{c}\text { Total } \\
\text { Government } \\
\text { Recurrent } \\
\text { Expenditure } \\
\text { on Transfers } \\
\text { (TGRT) }\end{array}$ \\
\hline 1999 & $22,449.41$ & 6.02 & 30.84 & 0.00 & 183.64 & 107.58 \\
\hline 2000 & $23,688.28$ & 8.52 & 131.05 & 17.04 & 144.53 & 203.69 \\
\hline 2001 & $25,267.54$ & 19.08 & 155.42 & 30.04 & 180.8 & 265.86 \\
\hline 2002 & $28,957.71$ & 16.2 & 163.81 & 57.08 & 266.51 & 225.15 \\
\hline 2003 & $31,709.45$ & 22.4 & 363.51 & 34.16 & 307.97 & 477.65 \\
\hline 2004 & $35,020.55$ & 31.38 & 382.50 & 72.20 & 306.77 & 610.7 \\
\hline 2005 & $37,474.95$ & 32.32 & 393.96 & 84.05 & 434.67 & 670.6 \\
\hline 2006 & $39,995.50$ & 35.47 & 249.33 & 101.21 & 522.2 & 594.05 \\
\hline 2007 & $42,922.41$ & 62.87 & 213.73 & 106.14 & 626.36 & 527.17 \\
\hline 2008 & $46,012.52$ & 68.74 & 381.20 & 137.90 & 731.02 & 739.66 \\
\hline 2009 & $49,856.10$ & 70.23 & 251.79 & 195.71 & 714.42 & 635.75 \\
\hline 2010 & $54,612.26$ & 76.12 & 415.66 & 183.48 & 1117.44 & 878.34 \\
\hline 2011 & $57,511.04$ & 77.6 & 527.18 & 131.52 & 1262.40 & 956.18 \\
\hline 2012 & $59,929.89$ & 79.34 & 679.30 & 147.10 & 1159.40 & 1145.60 \\
\hline 2013 & $63,218.72$ & 82.18 & 828.10 & 139.73 & 1111.82 & 967.83 \\
\hline 2014 & $67,152.79$ & 83.45 & 941.70 & 182.81 & 992.84 & 1392.93 \\
\hline 2015 & $69,023.93$ & 86.67 & 1060.38 & 208.11 & 1228.99 & 1520.01 \\
\hline 2016 & $67,931.24$ & 89.3 & 1584.11 & 168.00 & 1091.95 & 2047.42 \\
\hline
\end{tabular}

Source: Central Bank of Nigeria (CBN) Statistical Bulletin, 2016 (Various).

\subsection{Real Gross Domestic Product (RGDP)}

Real gross domestic product has been used in this study as a measure for economic growth in Nigeria. Available data on Table 1 above showed that real gross domestic product in Nigeria increased in almost all the years under review. For instance, in 1999, real gross domestic product (RGDP) stood at N22,449.41 billion and increased to N23,688.28 billion in 2000. The upward trend in real gross domestic product continued unabated reaching N35,020.55 billion high in 2004. Impressively, real gross domestic product of Nigeria continued to increase reaching N46,012.52 billion in 2008 year and this upward trajectory of the gross domestic product of Nigeria continued until it reached an all-time high of N69023.93 billion in 2015. However, it declined slightly to N67,931.24 billion in 2016, there by signaling the beginning of period when Nigeria suffered serious economic recession due to non diversification of its economy into agriculture and industry dwindling crude oil prices in the international market leading to 
high volatility of exchange rate of the domestic currency with dollar, the micro dependently massively.

\subsection{Government Recurrent Expenditures of National Assembly (GRENA)}

Available data in Table 1 showed that government recurrent expenditures of national assembly increased in almost all the years covered review. For instance, in 1999, government recurrent expenditures of Nigerian national assembly stood at N6.02 billion and increased steadily reaching N19.08 billion in 2001. However, it declined to N16.2 billion in 2002 but this decrease was quickly reversed in 2003 as government recurrent expenditures of national assembly started to increase steadily reaching N76.122 billion high in 2010. This upward trend in government recurrent expenditures of national assembly continued to increase steadily until it reached an all-time high of N89.3 billion in 2016.

\subsection{Government Recurrent Expenditures of Public Debt Servicing (GREPDTS)}

Available data in Table 1 showed that government recurrent expenditures of public debt servicing has fluctuated over time as it increased in some years and decreased in others. For instance, it stood at N30.84 billion in 1999 and increased steadily reaching N393.96 billion in 2005. However, in 2006 and 2007, government recurrent expenditures of public debt servicing decreased to N249.33 billion and N213.73 billion respectively. It went up to N381.20 billion in 2008 and decreased again to N251.79 billion in 2009. From 2010 to 2016, government recurrent expenditure of public debt servicing increased steadily from N415.66 billion to an all-time high of N1584.11 billion, respectively.

\subsection{Government Recurrent Expenditures of Pensions and Gratuities (GREPENG)}

Available data in Table 1 showed that government recurrent expenditures of pensions and gratuities had uneven growth in the period under review. It stood at N17.04 billion in 2000 and increased steadily reaching N57.08 billion in 2002. In 2003, government recurrent expenditures of pensions and gratuities decreased to N34.16 billion but recorded a steady increase in the years that followed reaching N195.71 billion in 2009. From 2010 to 2016, the upward and downward trend in government recurrent expenditures of pensions and gratuities continued and it reached an all-time high of N208.11 billion in 2015.

\subsection{Total Government Recurrent Expenditures of Administration (TGRA)}

Available data in Table 1 showed that total government recurrent expenditures of administration recorded periods of increase and periods of decrease in the years under review. In 1999, it stood at N183.64 billion and decreased to N144.53 billion in 2000. From 2001 to 2008, total government recurrent expend- 
itures of administration increased steadily from N180.8 billion to N731.02 billion, respectively. In 2009, total government recurrent expenditures of administration declined yet again to N714.42 billion but this trend was reversed as it increased steadily reaching an all-time high of N1262.40 billion in 2011. The upward and downward trend in total government recurrent expenditures of administration continued in the years that followed as it was valued at N1091.95 billion in 2016.

\subsection{Total Government Recurrent Expenditures of Transfers (TGRT)}

Total government recurrent expenditures of transfers increased in some years and decreased in others. In 1999, it stood at N107.58 billion and increased to N265.86 billion in 2001. The upward and downward trend in total government recurrent expenditures of transfer continued in the years that followed reaching an all-time high of N2047.42 billion in 2016.

\section{Discussion of Results}

\section{Descriptive Statistics}

This section presents the overall descriptive statistics result of the study, after analysis of its findings; the main empirical regression results would be presented and analyzed using ordinary least square function.

Table 2 represented the summary statistics of the variables of this study. Total number of observations for the study was 108 , owing to a time period of 18 years. The table showed the descriptive statistics of the study. It provided basic information of the performance, behavior and trend of data through time and space. Vital information such as the mean, median, maximum, minimum, standard deviation, skewness, kurtosis, Jarque-Bera statistics have been presented. The output of the process which included the total sum of each variable, the sum

Table 2. Descriptive statistics results.

\begin{tabular}{ccccccc}
\hline & GDP & GRENA & GREPDTS & GREPENG & TGRA & TGRT \\
\hline Mean & 45707.46 & 52.66056 & 486.3094 & 110.9044 & 687.9850 & 775.8983 \\
Median & 44467.46 & 65.80500 & 381.8500 & 118.8300 & 670.3900 & 653.1750 \\
Maximum & 69023.93 & 89.30000 & 1584.110 & 208.1100 & 1262.400 & 2047.420 \\
Std. Dev. & 16060.07 & 30.22721 & 397.1129 & 65.26203 & 408.5402 & 505.7589 \\
Skewness & 0.043234 & -0.269898 & 1.346410 & -0.182437 & 0.068242 & 0.900771 \\
Kurtosis & 1.638460 & 1.420277 & 4.290458 & 1.808589 & 1.435379 & 3.395641 \\
Jarque-Bera & 1.395951 & 2.090179 & 6.687422 & 1.164445 & 1850001 & 2.551562 \\
Probability & 0.497592 & 0.351660 & 0.035306 & 0.558655 & 0.396531 & 0.279213 \\
Sum & $822,734.3$ & 947.8900 & 8753.570 & 1996.280 & $12,383.73$ & $13,966.17$ \\
Sum Sq. Dev. & $4.38 \mathrm{E}+09$ & $15,532.63$ & $26,808.78$ & $72,405.26$ & $28,373.86$ & $43,484.65$ \\
Observations & 18 & 18 & 18 & 18 & 18 & 18 \\
\hline
\end{tabular}


of square deviation and the number of observations were also presented. The mean showed the average growth of GDP, GRENA, GREPDTS, GREPENG, TGRA and TGRT; with their respective values as 45707.46, 52.66056, 486.3094, $110.9044,687.9850$ and 775.8983 , respectively.

Gross domestic product (GDP) exhibited the highest growth rate of N45707.46bn. Also, the median showed the middle way between the maximum and minimum value. The maximum value for gross domestic product (GDP) was N69023.93bn and for expenditures on national assembly (GRENA) was N89.300bn, on public debt servicing (GREPDTS) was N208.100, on administration (TGRA) was N2047.420, respectively.

The above values for the maximum and minimum scores showed that gross domestic product (GDP) still maintained the optimum growth rate with the maximum and minimum values of N69023.93bn and N2244.41bn, respectively.

Considering the range of values between the maximum and minimum, it was also observed that gross domestic product (GDP) with a maximum N2249.41bn exhibited the highest variability as it had the highest standard deviation of N16060.07bn. It implies that GDP growth rate during this period did not follow a trend. It equally implied that there were fluctuations in the growth of the gross domestic product (GDP) of Nigeria within the period studied.

Skewness is associated with shape of he variables. That is, it is a measure of presence of symmetry, along the peak level. It is said to be symmetry if variables appeared the same to the left and right of the centre point. For a normal distribution, the skewness is zero; hence, literature supports any symmetric data that has skewness near zero. Negative values for he skewness is an indication that data are skewed left, it means that the left tail is long relative to the right tail. Also, when it is skewed right, it means that the right is long relative to the left tail. It was however, observed from the table above, that two of the variables: GRENA $(-0.269898)$ and GREPENG $(-0.182437)$ were negatively skewed, implying that their data were normally distributed around the centre point. However, positively skewed variables included GDP (0.043234), GREPDTS (1.346410), TGRA (0.068242) and TGRT (0.900771).

Kurtosis is associated with the distribution of series that is at peak level. It actually measured whether the data are heavy-tailed or light-tailed relative to a normal distribution. That is, data sets with high kurtosis tend to have heavy tails, while data sets with low kurtosis tend to have light tails. Kurtosis for a standard normal distribution is three. From the table above, it was observed that GREPDTS (4.290458) and TGRT (3.395641) exceeded 3, therefore they were picked as relative to a normal distribution. The normal distribution scores as measured with Jarque-Bera showed GDP at 1.396, GRENA at 2.090, GREPDTS at 6.687, GREPEND at 1.164, TGRA at 1.850 and TGRT at 2.552 with their relative probability values as $0.498,0.351,0.035,0.559,0.397$ and 0.279 , respectively. The relative probability further proved that all variables had normal distributions.

Below the paper shall pursue analysis of the result of tests and investigations it conducted using OLS functions in the main. 
Table 3. Ordinary Least Squares (OLS) Function results (Dependent variable: RGDP).

\begin{tabular}{ccccc}
\hline Independent Variable & Coefficient & Std. Error & t-statistic & Prob. \\
\hline C & 3.362638 & 0.129609 & 25.94456 & $0.0000^{* *}$ \\
$\ln$ (GRENA) & 0.041554 & 0.091803 & 0.452647 & 0.6596 \\
$\ln$ (GREPDTS) & 0.158418 & 0.078831 & 2.009585 & $0.0697^{*}$ \\
$\ln ($ GREPENG) & 0.082868 & 0.063809 & 1.298686 & 0.2206 \\
$\ln$ (TGRA) & 0.259748 & 0.079983 & 3.247524 & $0.0078^{* *}$ \\
$\ln$ (TGRT) & -0.027935 & 0.123028 & -0.227061 & 0.8245 \\
\hline
\end{tabular}

R-squared $=0.98 \approx 98 \%$; Adjusted R-squared $=0.98 \approx 98 \%$; F-statistic $=128.41$; DW $=1.61$. Source: Author's Computations (2018) from E-views 9.0 software package. Key: ${ }^{* *}=$ Significant at $1 \%$ level; ${ }^{*}=$ Significant at $5 \%$ level.

From these above results (Table 3), 1 percent increase in government recurrent expenditure on national assembly lead to 4 percent increases in real gross domestic product (proxy for economic growth) in Nigeria. The probability value of government recurrent expenditure on national assembly (0.6596) is greater than the test significant level (i.e. $\mathrm{P}>0.05$ ). Thus, the paper concluded that government recurrent expenditure on national assembly did not have significant impact on economic growth of Nigeria within the present studied. This present study corroborates, Ifere, Okoi and Eko [35] who argued that national assembly expenditure had a positive and significant relationship with economic growth in Nigeria. This outcome could be attributed to the increasing number of bills passed by the national assembly aimed at bettering the lives of Nigeria's citizens. As the positive impact of these bills grew, productivity increased thereby increasing Nigeria's economic growth.

Surprisingly, the study revealed that 1 percent increase in government recurrent expenditure on public debt servicing leads to 16 percent increase in real gross domestic product (proxy for economic growth) in Nigeria. The probability value of government recurrent expenditure on public debt servicing (0.0697) was greater than the test significant level (i.e. $\mathrm{P}>0.05$ ). With this, the paper could comfortably that government recurrent expenditure; of public debt servicing had weak significant impact on economic growth in Nigeria. This present study therefore has corroborated Gushibet and Tsenba [4] who argued that public debt had a positive but insignificant effect on economic growth in Nigeria. The present outcome could be attributed to the positive image which regular debt servicing might have brought to Nigeria thereby attracting more goodwill to the nation which if it could be well harnessed would lead to increase in economic growth in the future.

Thirdly, the study also showed that 1 percent increase in government recurrent expenditure of pensions and gratuities lead to 8 percent increase in real gross domestic product (mirror for economic growth) in Nigeria. The probability value of pension and gratuities expenditure $(0.2206)$ was greater than the test significant level (i.e. $\mathrm{P}>0.05$ ). Thus, the study concluded that pensions and gra- 
tuities recurrent expenditure did not have significant impact on economic growth in Nigeria. This outcome has profoundly corroborated Farayibi (2016), who argued that pension payment increases stock of investible fund thereby increasing economic growth ofthe nation. This finding could be attributed to the fact that when the Nigerian government spends on pension and gratuities payments, aggregate demand increases, consumption increases, economic activities increases thereby leading to increase in output of goods and services.

Fourthly, the study further demonstrated that 1 percent increase in total government recurrent expenditure on administration led to 26 percent increase in economic growth (proxied by GDP) in Nigeria. The probability value of total government recurrent expenditure on administration (0.0078) was less than the test significant level (i.e. $\mathrm{P}<0.05)$. Thus, the work concluded that total government recurrent expenditures on administration had a significant impact on economic growth in Nigeria. This study hence had corroborated, Ogbulu and Torbira [31] who established a positive and significant relationship between government recurrent expenditure on administration and economic growth of the country.

Finally, the study revealed that a percent increase in total government recurrent expenditure on transfers led to a percent decrease in real gross domestic product (proxy for economic growth) in Nigeria. The probability value for total government recurrent expenditure on transfers $(0.8245)$ was greater than the test significant level (i.e. $\mathrm{P}>0.05$ ). Thus, the study had rightly concluded that total government recurrent expenditure on transfers did not have significant impact on economic growth in Nigeria. This outcome had contrasted with Ogbulu and Torbira [31] who argued that government expenditure on transfers had a positive and significant effect on economic growth of Nigeria.

The coefficient of determination (adjusted R-squared) of 98 also showed that 98 percent of the variation in economic growth in Nigeria has been due to changes in government recurrent expenditures on national assembly, public debt servicing, pensions and gratuities, total recurrent expenditure on administration and total recurrent expenditure on transfers. The computed F-statistic (128.41) was less than the F-statistic critical value (3.20) and this has indicated that the model used in the study has been appropriate, reliable and significant and could be used for sound policymaking. The Durbin-Watson statistic of 1.61 lied within the acceptance region and it suggested that there was no presence of autocorrelation (since $2 \leq \mathrm{DW}<4$ ) prevalent in the study. Hence, there would be no reason to employ other test statistics to boost the outcome or results of our tests and analyses beyond the present state of affairs.

\section{Summary of Findings, Conclusion and Recommendations}

\subsection{Summary of Findings}

The findings of the present study are summarized thus below:

1) Government recurrent expenditures of the national assembly had a positive 
and insignificant impact on economic growth in Nigeria.

2) Government recurrent expenditures of public debt servicing had a positive and weak significant impact on economic growth in Nigeria.

3) Government recurrent expenditures of pensions and gratuities had a positive and insignificant impact on economic growth in Nigeria.

4) Total government recurrent expenditures of administration had a positive and significant impact on economic growth in Nigeria.

5) Total government recurrent expenditures of transfers had a negative and insignificant impact on economic growth in Nigeria.

\subsection{Conclusion}

The study was basically a recurrent-side approach to government expenditures in Nigeria as it evaluated the relationship between government recurrent expenditures and economic growth in Nigeria. As a result of this, the study specifically investigated impact of government recurrent expenditures on national assembly, public debt servicing, pensions and gratuities, total government recurrent expenditures on administration and total government recurrent expenditures on transfers on economic growth in Nigeria. Thus, government recurrent expenditures on national assembly, public debt servicing, pensions and gratuities, administration and transfers served as the independent variables while real gross domestic product served as the dependent variable. From the empirical evidence, the study revealed that only government recurrent expenditures on administration had a very positive and significant impact on economic growth in Nigeria within the specified period. However, government recurrent expenditures on public debt servicing also had a positive and significant influence on growth of the domestic economy. On the other hand, the study revealed that government recurrent expenditures on transfers negated economic growth in Nigeria although its effect was insignificant.

\subsection{Recommendations}

The following recommendations have been made in line with the findings of the study:

1) Government recurrent expenditure on national assembly is not detrimental to the Nigerian economy but such spending should be tailored to more meaningful items so that it could significantly influence the domestic economy.

2) Government should not renege in servicing its public debts since it preserves the nation's integrity as well as attract goodwill to Nigeria which if it is harnessed could lead to a significant increase in Nigeria's economic growth. That debt servicing had a positive and significant impact on growth shows that our level of debt servicing in terms of money committed to it via ways and means is not too bad but adequate and it should be sustained in the times to rise productivity and economic growth.

3) Government should spend more money on settling pensions and gratuities 
of its retired citizens as a way to increase aggregate demand and foster more economic growth in Nigeria.

4) Government recurrent expenditure on administration should be sustained but all leakages arising from such spending should be blocked in order to achieve more economic growth in Nigeria.

5) Government should desist from spending more on transfers as it could have a devastating effect on the nation's economy.

To the extent discussed above the paper has been able to make its contributions to knowledge in the times. Further studies are exposed to spring forth there-from with a view to extending the frontiers of knowledge with regard to the topic under discourse and been hinged on other related past literature.

\section{Conflicts of Interest}

The authors declare no conflicts of interest regarding the publication of this paper.

\section{References}

[1] Olugbenga, A.O. and Owoye, O. (2007) Public Expenditure and Economic Growth: New Evidence from OECD Countries. Business and Economic Journal, 32, 1059 1068.

[2] Oziengbe, S.A. (2013) The Relative Impacts of Federal Capital and Recurrent Expenditures on Nigeria's Economy (1980-2011). American Journal of Economics, 3, 210-221.

[3] Muhlis, B. and Hakan, Ç. (2003) Causality between Public Expenditure and Economic Growth: The Turkish Case. Journal of Economic and Social Research, 1, 53-72. http://www.mpra.ub.uni-muenchen.de/8576/

[4] Gushibet, S.T. and Tsenba, W.S.B. (2016) Impact of Public Expenditure on Economic Growth: Evidence from Nigeria's Data. International Journal of Advanced Studies in Economics and Public Sector Management, 4, 84-101.

[5] CBN (2016) Statistical Bulletin, Central Bank of Nigeria, Abuja.

[6] Ijaiya, G.T. (2000) Inflation and Poverty in Nigeria: A Calibration Analysis. International Journal of Business and Social Sciences, 7, 35-45.

[7] Nurudeen, A. and Usman, A. (2010) Government Expenditure and Economic Growth in Nigeria, 1970-2008: A Disaggregated Analysis. Business and Economics Journal, 2010, 1-11.

[8] Agomuo, Z. (2012) Relevance of Nigeria's National Assembly. Business Day Newspaper.

[9] Tuffour, J.K. (2012) An Analysis of the Effect of External Debt on Crowding-Out Effect of Private Investment in Ghana. Journal of Business Research, 6, 73-83.

[10] Kareem, R.O., Bakare, H.A., Ademoyewa, G., Bashir, N.O., Ologunla, S.E. and Arije, R. (2014) The Impact of Public Sector Spending on Economic Growth of Nigeria. Journal of Economics and Sustainable Development, 5, 216-224.

[11] Ukwueze, E.R. (2014) Public Expenditures and Economic Growth in Nigeria: 1961-2012. Ph.D. Thesis, Department of Economics, Faculty of Social Sciences, University of Nigeria, Nsukka.

[12] Njoku, C.O., Ugwu, K.E. and Chigbu, E.E. (2014) Government Public Expenditures: 
Effect on Economic Growth (The Case of Nigeria, 1961-2013). International Journal of Research in Management, Science and Technology, 2, 16-29.

[13] Omo, A. and Bashir, O.K. (2015) Oil Revenue, Public Spending and Economic Growth Relationships in Nigeria. Journal of Sustainable Development, 8, 113-123.

[14] Ogbuagu, M.I. and Ekpenyong, U.I. (2015) Estimating the Impact of the Components of Public Expenditure on Economic Growth in Nigeria (A Bound Testing Approach). International Journal of Economics, Commerce and Management, 3, 43-52.

[15] Shuaib, I.M., Igbinosun, F.E. and Ahmed, A.E. (2015) Impact of Government Agriculture on the Growth of the Nigerian Economy. Asian Journal of Agricultural EXtension, Economics and Sociology, 6, 23-33. https://doi.org/10.9734/AJAEES/2015/15369

[16] Udoffia, D.T. and Godson, J.R. (2016) The Impact of Federal Government Expenditure on Economic Growth in Nigeria (1981-2014). Greener Journal of Social Sciences, 6, 92-105. https://doi.org/10.15580/GJSS.2016.4.110116199

[17] Olayemi, I.A. (2017) Is Nigerian Growth Public Spending-Spurred? Asian Journal of Economic Modeling, 5, 354-363. https://doi.org/10.18488/journal.8.2017.53.354.363

[18] Obialor, M.C. (2017) Effect of Government Human Capital Investment on Economic Growth in Sub-Saharan Africa: Evidence from Nigeria, South Africa and Ghana (1980-2013). International Journal of Asian Social Science, 7, 328-339. https://doi.org/10.18488/journal.1/2017.7.4/1.4.328.339

[19] Nwankwo, D.J., Kalu, C.U. and Chiekezie, M.O. (2017) Fiscal Policy-Economic Growth Correlates: Further Evidence from Nigeria Economy. International Journal of Academic Research in Business and Social Sciences, 7, 1-11.

[20] Nwaoha, W.C., Onwuka, O.O. and Ejem, C.A. (2017) Effect of Aggregated and Disaggregated Public Spending on the Nigerian Economy (1980-2015). International Journal of Economics and Financial Research, 3, 44-53.

[21] Okoro, A.S. (2013) Government Spending and Economic Growth in Nigeria, (1980-2011). Singaporean Journal of Business Economics and Management Studies, 2, 81-92. https://doi.org/10.12816/0003892

[22] Nwaeze, C., Njoku, R. and Nwaeze, O.P. (2014) Impact of Government Expenditure on Nigeria's Economic Growth (1992-2011). The Macrotheme Review, 3, 79-87.

[23] Campodonico, J.F.B., Cassinelli, J.R.P. and Mesones, J.A. (2014) The Impact of Public Expenditures in Education, Health, and Infrastructure on Economic Growth and Income Distribution in Peru. Inter-American Development Bank, Fiscal and $\mathrm{Mu}$ nicipal Management Division. IDB Working Paper Series, No. 490. https://doi.org/10.2139/ssrn.2649490

[24] Ewubare, D.B. and Eyitope, J.A. (2015) The Effects of Public Expenditure on Agricultural Production Output in Nigeria. Journal of Research in Humanities and Social Science, 3, 7-23.

[25] Mudaki, J. and Masaviru, W. (2012) Does the Composition of Public Expenditure Matter to Economic Growth for Kenya? Journal of Economics and Sustainable Development, 3, 56-75.

[26] International Monetary Fund (2013) International Financial Statistics. International Monetary Fund, Washington DC.

[27] Bjork, G.J. (1999) The Way It Worked and Why It Won't: Structural Change and the Slowdown of U.S. Economic Growth. Praeger Publishers, Westport, CT.

[28] Keynes, J.M. (1936) General Theory of Employment, Interest and Money. Palgrave 
Macmilliam Publishers, London.

[29] Nworji, I.D. and Oluwalaiye, O.B. (2012) Government Spending on Road Infrastructure and Its Impact on the Growth of Nigerian Economy. International Journal of Management and Business Studies (IJMBS), 2, 24-30.

[30] Adewara, S.O. and Oloni, E.F. (2012) Composition of Public Expenditure and Economic Growth in Nigeria. Journal of Emerging Trends in Economic Management Science, 3, 403-407.

[31] Ogbulu, O.M. and Torbira, L.L. (2012) Budgetary Operations and Economic Growth: The Nigerian Perspective. British Journal of Arts and Social Sciences, 4, 181-191.

[32] Dada, M.A. (2013) Composition Effects of Government Expenditure on Private Consumption and Output Growth in Nigeria: A Single-Equation Error Correction Modeling. Romanian Journal of Fiscal Policy, 4, 18-34.

[33] Ojonugwa, U., Esther, A.A. and Hindatu, A.B. (2016) Government Expenditure and Economic Growth in Nigeria: A Cointegration and Error Correction Modeling. Scientific Research Journal, 4, 30-37.

[34] Osuala, A.E. (2010) Econometrics: Theory and Problems. Toniprints Services, Nigeria.

[35] Ifere, E.O., Okoi, O.B. and Eko, E.O. (2014) National Assembly Expenditure and Economic Growth in Nigeria: An Empirical Analysis. Macrothink Institute Research in Applied Economics, 6, 73-86. https://doi.org/10.5296/rae.v6i2.5560 